\title{
Isolation and Molecular Characterization of Antibiotic Producing Bacillus licheniformis Strains Isolated from
} Soil

\author{
Anhar Al-Turk' ${ }^{1}$ Nidal Odat ${ }^{2 *}$ (D) and Muhannad I. Massadeh ${ }^{1}$ (D) \\ ${ }^{1}$ The Hashemite University, Faculty of Science, Department of Biology and Biotechnology, 13115, Al-Zarqa, \\ Jordan. \\ ${ }^{2}$ Al-Balqa Applied University, Faculty of Science, Department Medical Labratories, 19117, Al-Salt, Jordan.
}

\begin{abstract}
Currently, there is an increase prevalence of antibiotic-resistant bacteria worldwide. Therefore, the need for characterization of naturally occuring antibiotics with less antibiotic resistance is required. Soil resources contains valuable antibiotic producing microorganisms that increasingly being utilized for the production of suitable antibiotics. Therefore, this study aimed at identifying an antibiotic bacteria with ability of producing antibiotic that is isolated from soil samples collected from AI Zarqa provenance, an arid area in Jordan. Morphological and biochemical characterization of the isolates were carried out and found that all of the isolates belong to Bacillus genus. Further confirmation of the characterization of the bacteria was done by ribosomal RNA and PCR. The results reveal that the isolates represent Basilluslicheniformis. These bacilli were further investigated for antimicrobial activities against 6 ATCC human pathogens viz., S. aureus, S. pneumonia, Salmonella typhi.. E. coli, P. mirabels and E. cloacae. Additionally, the results of Gas Chromatography Mass Spectrometry (GCMS) of ethyl acetate extracts for B. licheniformis secondary metabolites showed that they contain two main antimicrobial compounds namely Pyrrolo [1, 2-a] pyrazine-1, 4-dione,hexahydro and Trans-13-octadecenoic acid. The present work maybe suggests that soil isolates from the studied arid area include antibiotic producing strains that can be utilized commercially.
\end{abstract}

Keywords: Bacillus, Antibacterial activity, 16S rRNA, GCMS

\footnotetext{
*Correspondence: nidalodat@gmail.com

(Received: September 09, 2020; accepted: October 03, 2020)

Citation: Al-Turk A, Odat N, Massadeh MI. Isolation and Molecular Characterization of Antibiotic Producing Bacillus licheniformis Strains Isolated from Soil. J Pure Appl Microbiol. 2020;14(4):2363-2370. doi: 10.22207/JPAM.14.4.14

(C) The Author(s) 2020. Open Access. This article is distributed under the terms of the Creative Commons Attribution 4.0 International License which permits unrestricted use, sharing, distribution, and reproduction in any medium, provided you give appropriate credit to the original author(s) and the source, provide a link to the Creative Commons license, and indicate if changes were made.
} 


\section{INTRODUCTION}

The field of medicine and pharmacology are currently revolutionized thanks to the invention of antibiotics that successfully that has been fruitful in combating many infectious diseases. However, many infectious microbes have become increasingly resistant to most available antibiotic due to mainly the extensive these antimicrobial medicine ${ }^{1}$. Varied genetic mechanisms, such as mutation, genetic transfer, and epigenetic, have been adopted by resistant pathogens to make them successful adapted to antibiotics ${ }^{2}$. Antibiotics and antimicrobial metabolites extracted from microorganisms that inhabit environmental habitats, such soil, are providing an important role in fighting microbial disease and shown to be a promising source of new novel antibiotics ${ }^{3}$. Natural soil in general has a high biodiversity of bacteria and provide an important resource for these microbial diversity for possible novel antibiotics ${ }^{4}$. In fact, several medicinally new antibiotics have been characterized and identified from bacterial that inhabit varied natural soil, isolated from different soil samples ${ }^{5,6,7}$. The Bacillus is a heterogenous genera of bacteria with species that contain enormous antimicrobial compounds that act as agent of fighting several microbial diseases ${ }^{8}$. Among the most important species of bacteria that produce medically importan antibiotics are beloging to the genus Bacillus ${ }^{9}$. These species and other of Bacillus are among the most abundant bacterial strains found in soil with the ability of endospore-forming and Gram positive bacteria. Many investigations have been carried out to isolate different strains of terrestrial bacillus and identify their antimicrobial activities. This study attempts using biochemical and 16S rRNA to identify the microbial isolates from an arid are, Al Zarqa, of Jordan and to determine their antimicrobial activities.

\section{MATERIAL AND METHODS Microorganisms}

Based on the study of Massadeh and Mahmoud $^{10}$, new isolates of antagonistic strains were gathered from soil that was collected from the Hashemite University Campus area and identified as Bacillus species. Three isolates were chosen for further screening of antimicrobial activities and possible production of secondary metabolites. Each isolate was maintained on nutrient agar slants, and preserved at $4^{\circ} \mathrm{C}$.

\section{Isolates identification}

The isolates were characterized to the genus level by based on their morphology and biochemical characteristics ${ }^{11}$. The culture characteristics include colony morphology (size, opacity, form, elevation and margins), Gram reaction, spore formation, motility test, and Biochemical reactions. Further identification to the species level was achieved by using Microgen Bacillus-IDkits (Microgen bioproducts, UK) provided with Microgen identification software (MID-60).

\section{Molecular identification of the isolates DNA extraction}

The DNA of each bacterial strains was isolatedfrom a 24 hours old pure culture based on methodology of bacterial DNA extraction kit (Wizard ${ }^{\circledR}$, Promega, USA). The DNA was kept frozen until sequencing.

16S rRNA gene amplification and sequencing

Two universal PCR primers were manufactured to amplify approximately $1,300 \mathrm{bp}$ a region of $16 \mathrm{~S}$ ribosomal RNA gene: the forward primer $63 f$ ( $5^{\circ}$-CAG GCC TAA CAC ATG CAA GTC-3') and the reverse primer $1387 \mathrm{r}$ ( $5^{\circ}$-GGG CGG WGT GTA CAA GGC-3').The PCR mixtures contained approximately $2 \mu \mathrm{l}$ of DNA and $1 \mu$ l of each primer and $12.5 \mu$ l of DNA master mix (Promega, USA) and about $8 \mu \mathrm{l}$ of double distelled water. The reactions of PCRwere performed with a cycler (biorad thermal cycler). The cycler was programmed to perform $94^{\circ} \mathrm{C}$ for $30 \mathrm{~min}$, followed by 25 cycles consisting of $94^{\circ} \mathrm{C}$ for $45 \mathrm{~s}, 55^{\circ} \mathrm{C}$ for $45 \mathrm{~s}$, and $72^{\circ} \mathrm{C}$ for $90 \mathrm{~s}$. followed by a final extension step of 10 min. at $72^{\circ} \mathrm{C}$. PCR products were visualized by $1 \%$ agarose gel electrophoresis. The PCR product was properly labeled and sent to Princess Haya Biotechnology Center (Irbid-Jordan) for being identified by sequencing of the PCR products.

\section{Antibacterial activity \\ Cell-free extract preparation}

Each isolate was cultivated in a flask containing a $100 \mathrm{ml}$ of nutrient broth. The flasks were incubated at $30^{\circ} \mathrm{C}$ in a shaking incubator running at $150 \mathrm{rpm}$ for 3 days and then subjected to centrifugation and then filltered with standard memebrane. 


\section{Ethyl acetate extract preparation}

To concentrate the isolates metabolites, each extract was mixed with ethyl acetate at a ratio of $4: 1$. The mixture was agitated at $100 \mathrm{rpm}$ for 2 hrs in an incubator shaker (Human Lab, Korea). The organic phase was concentrated by evaporating the ethyl acetate at $45^{\circ} \mathrm{Cand}$ the resulting extract was stored at $4^{\circ} \mathrm{C}$ until use $\mathrm{e}^{10}$.

\section{Antimicrobial test}

The inhibitory effect of each bacterial extract was tested against different pathogens using agar-well diffusion method. The tested pathogenic microorganisms include 2 Grampositive bacteria (Streptococcuspneumonia ATCC 6303 and Staphylococcus aureus ATCC 11632) and 4 Gram-negative bacteria (Proteus mirabilis ATCC, Enterobactercloacae ATCC 13182., Escherichia coli ATCC 10145, and Salmonella typhi. ATCC 13076). A suspension of each test pathogens $(0.1 \mathrm{ml})$ of an O.D $_{600}$ of 0.4 was spread on NA plates, and wells of $6 \mathrm{~mm}$. A $40 \mu \mathrm{l}$ of extract was placed into the wells, and the plates were placed under $37^{\circ} \mathrm{C}$ for about 24 hours. The diameter of affected zone was estimated with calipers as $\mathrm{mm}$. The antibiotic Ciprofloxacin (5 mcg) was used as a control.

Characterization of antibacterial metabolites Proteolytic digestion

For testing proteolysis of metabolites was employed with a slight modification accordingto the procedure describe eleswhere ${ }^{12}$. One milliliter of eythl acetate extract showing antibacterial activity was subjected to proteolytic digestion using a $100 \mathrm{mg} / \mathrm{ml}$ proteinase $\mathrm{K}$. The samples then were incubated overnight at $56^{\circ} \mathrm{C}$. After incubation, samples were tested for antibacterial activity by the agar well diffusion method and a sample of ethyl acetate extract without proteinase $\mathrm{K}$ was used as a negative control.

\section{Thermostability test}

Each extract was incubated at $80^{\circ} \mathrm{C}$ for $1 \mathrm{hr}$. and the tested for antibacterial activity by the agar welldiffusion method. A sample of ethyl acetate extract without heat treatment was used as a negative control.

Detection of antibacterial compounds by Gas chromatography/Mass spectrometry (GC-MS)

Antibacterial metabolites in ethyl acetate extract were characterising using GC-MS by inserting a $1 \mu$ solution into an Agilent 6890 GC detector GC-MS. The temperature level procedure was set at $80^{\circ} \mathrm{C}$ for about $3 \mathrm{~min}$ and then was increased to 80 to $500^{\circ} \mathrm{C}$. Chemistation system was used to compare the percntage of mass to charge using standared spectrum library ${ }^{13}$.

\section{RESULT AND DISCUSSION \\ Morphological characteristics and biochemical activities}

The major aim of current research was to identify and characterize bacterial strains isolated from soil Al Zarqa arid area that has the ability of producing natural antibiotic. The soil in this area was chosen as it contains large bacterial community with potential of antibiotic production ${ }^{10}$.

The results revealed 3 isolates with mainly yellow-white opaque morphological characteristic for studied colonies in accordance with similar studies that suggested soil as an important natural resource of medically important bacteria ${ }^{14}$. In agreement with similar the resultsthe biochemical tests of the four isolates revealed that all isolated were positive for catalase production ${ }^{15}$. Additionally, Microgen Bacillus-ID identified 3 possible isolates with varied percentage of probability: B. subtilis, $82.7 \%$, B. licheniformis with both $37.9 \%$ and $80.2 \%$ (Table 1). Moreover, the results showed that are positive to citrate utilization and have significant capability of fermentation of the sugars cellobiose, mannitole, mannose, salicin, sucrose, trehalose and xylose (Tables 2).

Table 1. Identification of species of the four isolates by Microgen Identification System Software (MID-60)

\begin{tabular}{|c|c|c|c|}
\hline Isolate & Identification & $\begin{array}{l}\text { Percent } \\
\text { probability }\end{array}$ & Identification comments \\
\hline 1 & B. subtilis & $82.69 \%$ & $\begin{array}{l}\text { Acceptable Identification, additional tests may improve the } \\
\text { identification }\end{array}$ \\
\hline 2 & B. licheniformis & $37.94 \%$ & Identification to the species level will require additional tests \\
\hline 3 & B. licheniformis & $80.18 \%$ & Acceptable Identification \\
\hline
\end{tabular}


Genetic characterization of bacterial strains by using ribosomal RNA

To confirm the identification and the classification of the studied strains all isolates were subjected to advanced identification using $16 S$ rRNA sequencing ${ }^{16}$. DNA of each isolate was extracted, amplified in PCR, checked in electrophoresis and finally sequenced. Fig. 1 and Table 3 shows the main products of gel electrophoresis and identification according to $16 \mathrm{~S}$ RNA sequencing. Moreover, a phylogenetic tree, constructed by Neighbor-joining, showed a four major group of Bacillus strains that clustered based on their sequence similarity of the 16S rRNA gene from all strains ${ }^{17}$ (Fig. 2). This clustering method is preferable to the conventional biochemical tests as it reveals the identification of isolates within 2-3 days compared to several weeks ${ }^{18}$. In agreement with several previous reports our results revealed that ribosomal RNA analysis is an efficient method

Table 2. Biochemical reactions of using the test of Microgen Biochemical ID Software Microgen GN$\mathrm{A}($ after $24 \mathrm{~h}$ )

\begin{tabular}{llll}
\hline $\begin{array}{l}\text { Reaction } \\
\text { name }\end{array}$ & 1 & 2 & 3 \\
\hline
\end{tabular}

\begin{tabular}{lccc}
\hline ARA & + & + & + \\
CEL & + & + & + \\
INO & - & + & - \\
MAN & + & + & + \\
MNS & + & + & + \\
RAF & - & - & - \\
RHF & - & - & - \\
SAL & + & + & + \\
BOR & + & + & + \\
SUC & + & + & + \\
TRE & + & + & + \\
XYL & + & + & + \\
ADO & - & - & + \\
GAL & + & - & + \\
MDM & - & - & - \\
MDG & + & + & + \\
INV & - & - & + \\
MLZ & - & - & - \\
INO & ---- & --- & --- \\
ONPG & + & + & + \\
ARG & - & - & - \\
CIT & + & + & + \\
VP & --- & --- & --- \\
NIT & --- & --- & --- \\
\hline
\end{tabular}

for classification of bacteria and provide support for earlier studies which have shown that Bacillus species as common bacteria occur in soil ${ }^{19}$.

\section{Antimicrobial activity}

The antimicrobial activity of the 3 isolates was studied against tested human pathogens. The results revealed that the ethyl acetate extract of the 3 isolates of $B$. licheniformis DSM 13 have an inhibitory effect against all test pathogens except for E. coli ATCC 10145 and Salmonella typhi. ATCC 13076 (Table 4; Fig. 3). It was found that the highest antimicrobial activitywas achieved by the extract $B$. licheniformis DSM 13 (isolate 1) against S. Aureus ATCC 11632 where the inhibition zone was 13.33 $\pm 0.58 \mathrm{~mm}$, while the lowest antimicrobial activity was exhibited by $B$. licheniformis DSM 13 (isolate 2) extract against $E$. cloacae ATCC 13182, P. mirabilis ATCC 12453 and S. pneumonia ATCC 6303 with inhibition zones of $10.33 \pm 0.58 \mathrm{~mm}$ (Table 4). Previous reportesindicated that $B$. licheniformis is widely distributed in nature and can readily be isolated from soils ${ }^{3}$. Moreover, $B$. licheniformis has been applied widely for producing extracellular enzymes, antibiotics, and special chemicals with a low risk of adverse effects to human health or the environment ${ }^{20}$.

\section{Characterization of ethyl acetate extract of B. licheniformis isolates}

The extracts were subjected to heat treatment and proteolysis by enzymes. The results revealed that heat treatment of the etheyl acetate extracts of the 3 isolates did not reduce the antibacterial activity. The activity could still be demonstrated even after subjecting the extracts to $80^{\circ} \mathrm{C}$ for $1 \mathrm{hr}$. Some reportes indicated that the thermal stability of many antibacterial

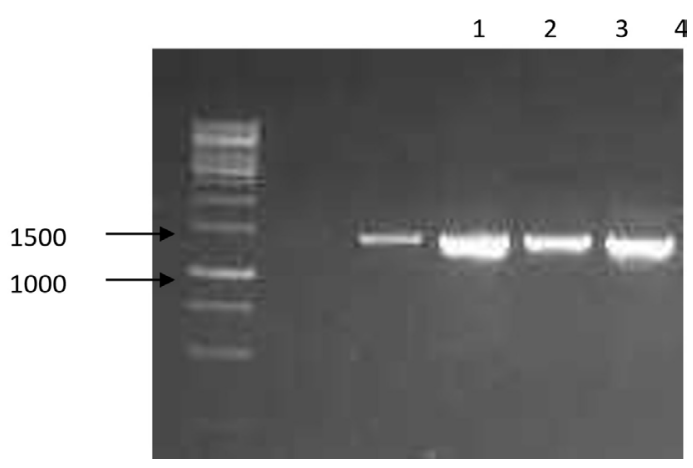

Fig. 1. PCR product with primers $63 \mathrm{f}$ and $1387 \mathrm{r}$ 
compounds isolated from $B$. licheniformis ${ }^{21,22}$. Other, hovere, claimed that the most metabolites of Bacillus sp. were proved to be stable at different temperatures ${ }^{23}$. On the other hand, incubating the extracts supplemented with Proteinase $\mathrm{K}$ did not affect the antibacterial activity of the extracts of the 3 active isolates suggests that the active compounds are not proteinaceous in nature.

\section{GCMS analysis}

Chemical investigations for the 3 ethyl acetate extracts based on GCMS indicated the identification of 2 major compounds (Table 5): (1) Pyrrolo [1, 2-a] pyrazine-1, 4-dione, hexahydro with a retention time of $12.397 \mathrm{~min}$. It was evident that this cyclic peptide is produced by some Streptomyces strains and sponge-associated

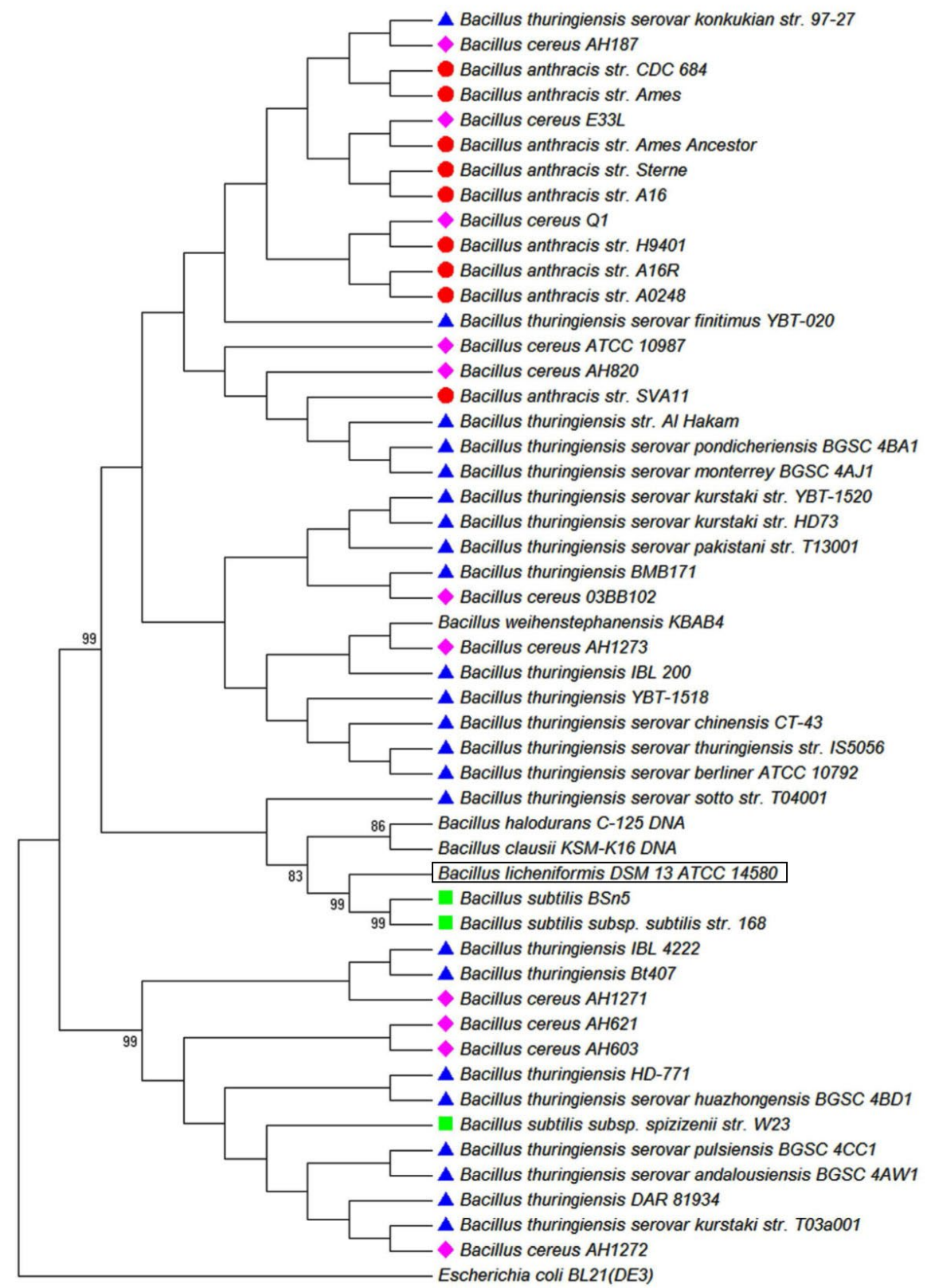

Fig. 2. Phylogenetic tree constructed by Neighbor-joining based on the sequences of the $16 \mathrm{~S}$ rRNA gene from 50 Bacillus strains (Wang and Ash, 2015) 
marine bacteria, in addition to some endophytes. Some researchers reported the isolation of Streptomyces strain MUSC $149^{\top}$ mangrove soil with a strong antioxidant activity ${ }^{24}$. The chemical analysis this strain's extract revealed the identification of Pyrrolo[1,2-a] pyrazine-1,4-dione, hexahydro as the antioxidant agent. On the other hand, some researchersidentified the presence of this compound in the extract of an Antarctic endophytic fungus exhibiting a strong antibacterial activity against $E$. coli, Pseudomonas aeruginosa and Enterococcus faecalis ${ }^{13}$. Moreover, this compound was produced by sponge associated bacteria (SAB) that was capable of inhibiting Vibrio alginolyticus ${ }^{25}$. (2) Trans-13-octadecenoic acid with a retention time of $16.127 \mathrm{~min}$. this Trans fatty acid was detected in tuber extracts of Solena amplexicaulis plant and has been reported as antiinflammatory and cancer compound ${ }^{26}$.However, other scientists identified this compound as an anti-inflammatory and antimicrobial compound ${ }^{22}$.

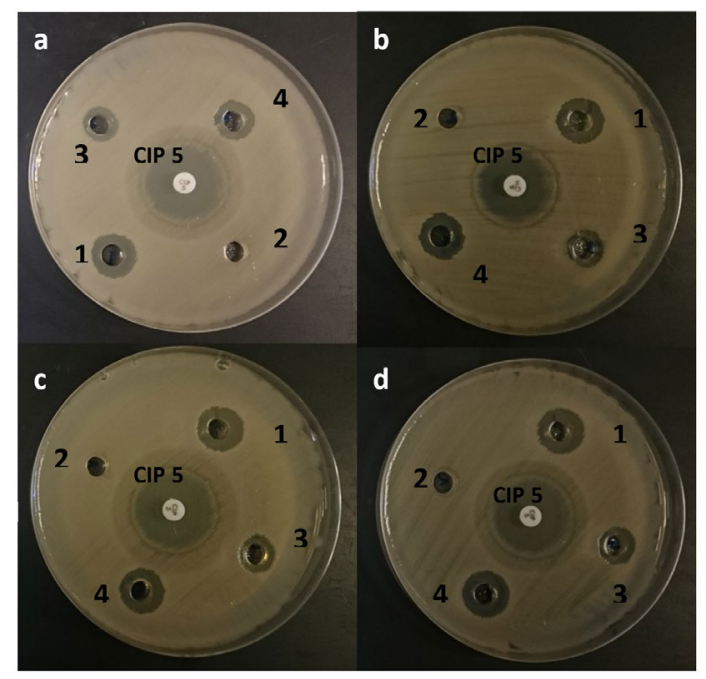

Fig. 3. Antimicrobial activity of the 3 isolates against the test pathogens: In this figure: a: Enterobacter sp., b: P. mirables, c: Staphylococcus sp., d: Streptococcus sp. No. 2 well and CIP 5 (Ciprofloxacin $5 \mu \mathrm{g} /$ disc) were used as a negative and positive control.

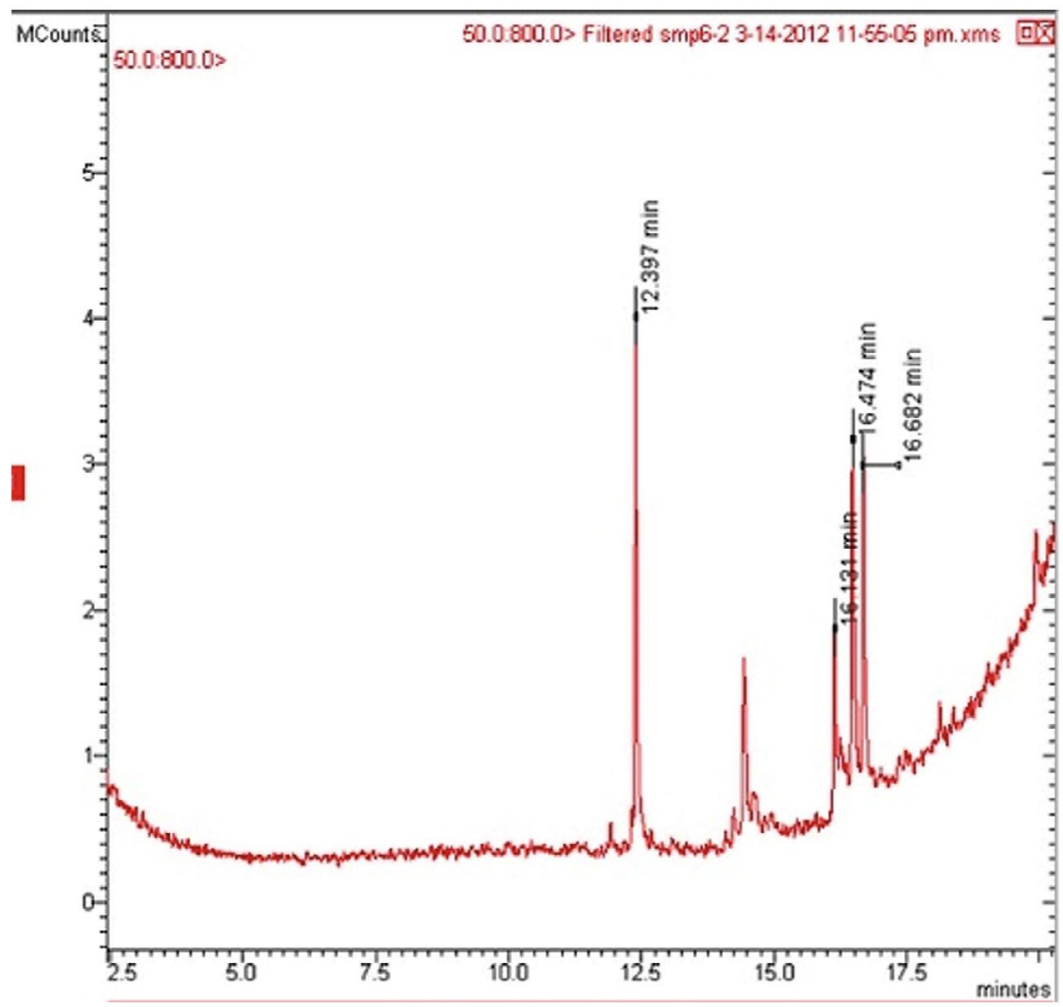

Fig. 4. Chromatogram showingresults of the major compounds from the active isolates. 
Table 3. Classification of bacterial strains according to $16 \mathrm{~S}$ rRNA (results obtained from BLAST/NCBI)

\begin{tabular}{llcl}
\hline Isolate & Classification & Ident & Accession No. on BLAST \\
\hline 1 & B. licheniformis DSM 13 & $87 \%$ & NR 118996.1 \\
2 & B. licheniformis DSM 13 & $90 \%$ & NR 118996.1 \\
3 & B. licheniformis DSM 13 & $97 \%$ & NR 118996.1 \\
\hline
\end{tabular}

Table 4. Antimicrobial activity of the three isolates of $B$. lichinifomis against test pathogens

\begin{tabular}{lcccc}
\hline Pathogen & \multicolumn{2}{c}{ Diameters of inhibition zone $(\mathrm{mm})$ by the four isolates } & \\
\cline { 2 - 4 } & 1 & 2 & 3 & CIP 5 \\
\hline E. cloacae ATCC 13182 & $13.00 \pm 1.00$ & $10.33 \pm 0.58$ & $12.33 \pm 0.58$ & $21.33 \pm 0.58$ \\
P. mirabilis ATCC 12453 & $12.67 \pm 0.58$ & $10.33 \pm 0.58$ & $11.67 \pm 0.58$ & $22.00 \pm 1.00$ \\
E. coli ATCC 10145 & 0 & 0 & 0 & 0 \\
Salmonella typhi ATCC 13076 & 0 & 0 & 0 & 0 \\
S. pneumonia ATCC 6303 & $12.67 \pm 0.58$ & $10.33 \pm 0.58$ & $11.67 \pm 0.58$ & $20.33 \pm 0.58$ \\
S. aureus ATCC 11632 & $13.33 \pm 0.58$ & $11.67 \pm 0.58$ & $12.67 \pm 0.58$ & $22.00 \pm 1.00$ \\
\hline
\end{tabular}

Table 5. Gas chromatogram results of the major compounds of the three active isolates

\begin{tabular}{lll}
\hline isolate & \multicolumn{1}{c}{ Compound } & $\begin{array}{l}\text { Retention } \\
\text { time (min) }\end{array}$ \\
\hline \multirow{2}{*}{1} & Pyrrolo [1, 2-a] pyrazine-1, 4-dione, hexahydro & 12.397 \\
& Trans-13-octadecenoic acid & 16.127 \\
2 & Pyrrolo [1, 2-a] pyrazine-1, 4-dione, hexahydro & 12.397 \\
& Trans-13-octadecenoic acid & 16.127 \\
3 & Pyrrolo [1, 2-a] pyrazine-1, 4-dione, hexahydro & 12.397 \\
\hline
\end{tabular}

\section{CONCLUSION}

The miss use of antibiotics has led to the evolution of pathogens with resistance to major available antibiotics. Accordingly, natural habitat such as soil are emerging procedure for the synthesis of new, safe and developed antibiotics. Three antagonistic bacterial strains were isolated from the soil of an arid area of Hashemite University and identified to be $B$. licheniformis based on biochemical tests and 16S rRNA gene sequencing with antibacterial activity against important human pathogens. Our finding promote that the bacterial strains obtained from the studied soil sables can be exploit commercially. Based on our study, we recommend further research that aim to use MIC to determine antibacterial activities, in addition to molecular docking and in vivo investigations to identify active compounds.

\section{ACKNOWLEDGMENTS}

We acknowledge the Hashemite University of Jordan for facilitating the conduct of this article.

\section{CONFLICT OF INTEREST}

The authors declare that there is no conflict of interest.

\section{AUTHORS' CONTRIBUTION}

All Authors contributed equally to literature collection, designing and writing the manuscript.

\section{FUNDING}

This work was financially funded by the Deanship of Research of the Hashemite University. Grant number is 1600204/9. 


\section{ETHICS STATEMENT}

Not applicable.

\section{DATA AVAILABILITY}

All datasets generated or analyzed during this study are included in the manuscript.

\section{REFERENCES}

1. Cars O, Hogberg LD, MurrayM, etal.Meeting thechallenge of antibiotic resistance. BMJ. 2008;18:337:a1438. doi: 10.1136/bmj.a1438

2. Bachoual R, Tankovic J, and Soussy C.J. Analysis of the mutations involved influoroquinolone resistance of in vivo and in vitro mutants of Escherichia coli. Microb Drug Resist. 1998;4:271-276. doi: 10.1089/ mdr.1998.4.271

3. Kumar D, Kumar S. Antimicrobial metabolites and antibiotics obtained from different environmental sources. Int J Pharm Res Allied Sci. 2016;5:85-90.

4. Amin M, Rakhisi R, Ahmady AZ. Isolation and Identification of Bacillus species from soil and evaluation of their antibacterial properties. Avicenna J Clin Microb Infec. 2015;2:e23233.

5. Griffith RS. Introduction to vancomycin. Rev Infect Dis. 1981;3:200-204. doi: 10.1093/clinids/3.Supplement_2. S200

6. Umezawa $\mathrm{H}$, Ueda M, Maeda $\mathrm{K}$, et al. Production and isolation of a new antibiotic: kanamycin. J Antibiot. 1957;10:181-188.

7. Staunton J, Wilkinson B. Biosynthesis of erythromycin and rapamycin. Chem Rev. 1997;97:2611-2630. doi: 10.1021/cr9600316

8. Sumi CD, Yang BW, Yeo I-C, Hahm YT. Antimicrobial peptides of the genus Bacillus: a new era for antibiotics. Can J Microbiol. 2015;61:93-103. doi: 10.1139/cjm-2014-0613

9. Yilmaz M, Soran $\mathrm{H}$, Beyatli Y. Antimicrobial activities of some Bacillus spp. Strain isolated from the soil. Microbiological Research. 2005;161:127-131. doi: 10.1016/j.micres.2005.07.001

10. Massadeh MI, Mahmoud S. Antibacterial activities of soil bacteria isolated from Hashemite University area in Jordan. Jordan J Biol Sci. 2019;12:503-511.

11. Brawn A. Benson's Microbiological Applications: Laboratory Manual in General Microbiology, $9^{\text {th }}$ edition, McGraw-Hill, New York. 2004.

12. Boottanun P, Potisap C, Hurdle JG, Sermswan RW. Secondary metabolites from Bacillus amyloliquefaciens isolated from soil can kill Burkholderia pseudomallei. AMB Express. 2017;7:16-27. doi: 10.1186/s13568-0160302-0

13. Melo I, Santos S, Rosa L, et al. Isolation and biological activities of an endophytic Mortierella alpine strain from the Antarctic moss Schistidium antarctic. Extremophiles. 2014;18:15-23. doi: 10.1007/s00792013-0588-7
14. Kaur S, Kaur J, Pankaj PP. Isolation and characterization of antibiotic producing microorganisms from soil samples of certain area of Punjab region of India. Int J Pharm Clin Res. 2014;6:312-5.

15. Yunus FN, Khalid ZZ, Rashid F, Ashraf A, Iqbal MN, Hussain F. Isolation and screening of antibiotic producing bacteria from soil in Lahore city. PSM Microbiology. 2016;1:1-4.

16. Janda JM, Abbott SL, 16S rRNA gene sequencing for bacterial identification in the diagnostic laboratory: pluses, perils, and pitfalls. J Clin Microbiol. 2007;45(9):2761-2764. doi: 10.1128/JCM.01228-07

17. Wang A, Gavin J. Ash. Whole genome phylogeny of Bacillus by feature frequency profiles (FFP). Scientific Report. 2015;5:1-14. doi: 10.1038/srep13644

18. Jill E, Clarridge III. Impact of $16 \mathrm{~S}$ rRNA gene sequence analysis for identification of bacteria on clinical microbiology and infectious diseases. Clin Microbiol Rev. 2004;17:840-62. doi: 10.1128/CMR.17.4.840862.2004

19. Abbas S, Senthilkumar R, Arjunan S. Isolation and molecular characterization of microorganisms producing novel antibiotics from soil sample. Eur J Experiment Biol. 2014;4:149-55.

20. Abdel-Mohsien H, Sasaki T, Tada C, Nakai Y. Characterization and partial purification of a bacteriocin-like substance produced by thermophilic Bacillus licheniformis $\mathrm{H} 1$ isolated from cow manure compost. Animal Science Journal. 2011;82:340-351. doi: 10.1111/j.1740-0929.2010.00835.x

21. Beric T, Stankovic S, Draganic V, Kojic M, Lozo J, Fira D. Novel antilisterial bacteriocin licheniocin 50.2 from Bacillus licheniformis VPS50.2 isolated from soil sample. J Appl Microbiol. 2013;116(3):502-510. doi: 10.1111/jam.12393

22. Smitha $\mathrm{S}$, Bhat $\mathrm{S}$. Thermostable Bacteriocin BL8 from Bacillus licheniformis isolated from marine sediment J Appl Microbiol. 2012;114(3):688-694. doi: 10.1111/ jam.12097

23. Maldonado M, Corona J, Gordillo M, Navarro A. Isolation and partial characterization of antifungal metabolites produced by Bacillus sp. IBA 33. Curr Microbiol.2009;59:646-650. doi: 10.1007/s00284-0099489-5

24. Ser H-L, Ab Mutalib N-S, Yin, W-F, Chan K-G, Goh B-H, Lee $\mathrm{L}-\mathrm{H}$. Evaluation of antioxidative and cytotoxic activities of Streptomyces pluripotens MUSC 137 isolated from mangrove soil in Malaysia. Front Microbiol. 2015;6:1398. doi: 10.3389/fmicb.2015.01398

25. Durai S, Vigneshwari L. Balamurugan K. Caenorhabditis elegans-based in vivo screening of bioactives from marine sponge-associated bacteria against Vibrio alginolyticus. J Appl Microbiol. 2013;115:1329-1342. doi: 10.1111/jam.12335

26. Krishnamoorthy K, Subramaniam P. Phytochemical Profiling of Leaf, Stem, and Tuber Parts of Solena amplexicaulis (Lam.) Gandhi Using GC-MS. Int Sch Res Notices. 2014;2014:1-13. doi: 10.1155/2014/567409 